\title{
Mountains Under Climate and Global Change Conditions - Research Results in the Alps
}

\author{
Oliver Bender, Axel Borsdorf, Andrea Fischer and Johann Stötter \\ Institute of Mountain Research: Man and Environment, Austrian Academy of Sciences \\ Austria
}

\section{Introduction}

Mountain regions are often marketed with statements suggesting "..., where time has stood still." Anyone who believes such statements is in for a disappointment as, of course, time does not stand still in the mountains, on the contrary: it is there that, behind the proffered Disneyland of mountain traditions, change often happens faster than in the lowlands. Global Change as climate change is hitting ecologically and economically sensitive mountain regions. Globalization reaches areas that adhere to a small-scale patchwork of social and economic structures, ill prepared for external impacts and global competition. It takes over traditional cultures and changes the way we interact, what we wear, what we eat, the music we listen to. Political agency is passed on to new integrative spatial units, to the global economy and political agreements. This shifts the responsibility for shaping our living environment to extranational bodies and reduces agency at national and regional level. In addition, coherent mountain regions are often spread across several states, which makes them potential or actual contended spaces.

Global Change research in mountain regions has to date focused on climate change (EEA, 2004; Kohler \& Maselli, 2009) while the impact of globalization has not received anything like as much attention (Borsdorf et al., 2008; Jandl et al., 2009). In reality, both phenomena interact and can only be analysed and evaluated in an integrative manner.

This chapter aims to look at Global Change from different perspectives and in an integrative approach. Our case in point are the Alps and, within them, mainly the Austrian Alps where the authors concentrate their research. After analysing the status quo, we shall present ongoing political processes, programmes and research and define the issues. Climate change concerns all spheres of nature and different subareas of the anthroposphere. It is in the cryosphere that change becomes most clearly visible, especially on glaciers and in permafrost areas, but also in the valleys. These lower lying areas face increased hazards but also new economic opportunities for agriculture and tourism, which we will discuss before closing with an outlook on future challenges.

\section{The Alps - a case in point of a mountain area and its political dimension}

The Alps - as defined by the Alpine Convention - cover an area of roughly 190,000 $\mathrm{km}^{2}$ and are populated by more than 14 million inhabitants plus another 120 million annual visitors (Bätzing, 2003). They provide resources for up to a third of the European population. Three 
large streams, the Rhine, the Rhone and the Po originate in the Alps, most of the water for the Danube comes from there, justifying their by-name of 'water tower of Europe'. This water is nourishment, process water and provider of clean and renewable energy as well as peak electricity for the European grid.

The Austrian share of the Alps makes up two thirds of the state territory but only $40 \%$ of Austrians live in the mountains. Permanent settlement is only possible up to ca. $2000 \mathrm{~m}$ a.s.l. This means that $75 \%$ of the Alpine area can only be settled seasonally or not at all. Human settlements thus reach the upper altitudinal limit and with it an ecologically highly sensitive border area. At the same time, the Alps represent a hotspot of biodiversity and an important gene pool as well as pools of cultural diversity and are a recreation area of global stature. Scientists may see them as open-air laboratories of Global Change. Here, especially, strategies for sustainable regional development are needed to minimize risks and to leverage opportunities. They can help maintain a unique area in its potency for inhabitants, visitors and for the extra-Alpine population that depends on its resources.

In November 1971, UNESCO established the 'Man and the Biosphere' research programme. It posed questions about the interaction between humans and their environment from a joint natural and social sciences point of view, questions that could be vital for our future. Importantly, the sixth project in this programme, 'Impact of human activities on mountain ecosystems' was dedicated to the mountains of the world. The first UN conference 'On the Human Environment' was held in Stockholm in June 1972. The recommendations from this meeting shaped the ensuing international mountain conferences. The same year saw the publication of the Club of Rome's famous report 'The Limits to Growth' (Meadows et al., 1972). Its much debated projections of exponential growth of populations, economy and technology started research into globalization.

Many international mountain conferences followed over the next years. In 1983, the mountain centre ICIMOD for all eight states of the Hindu Kush-Himalaya was established in Kathmandu; in 1986, the African Mountain Association formed in Ethiopia, followed in 1991 in Chile by the Andean Mountain Association. On this basis, the developing countries enthusiastically supported the proposal of a mountain chapter in the Agenda 21 at the third preparatory conference for Rio in the autumn of 1991. This chapter 13, 'Managing Fragile Ecosystems: Sustainable Mountain Development', was then passed unanimously at the socalled Earth Summit in Rio de Janeiro in June 1992. This amounts to a global recognition of the world's mountains, their resources and their problems (Messerli, 2010).

In 1991, the Alpine Convention was signed by eight Alpine states. It formed the first crossborder agreement based on the idea of sustainable regional development in a mountain area. A similar convention is currently being prepared for the Carpathians.

In 1997, the UN General Assembly for the evaluation of Agenda 21 was fundamental to rethinking the global significance of mountains. The delegates understood that mountains preserve a series of common goods, such as vast treasures of biological and cultural diversity, that they are water towers for an increasingly thirsty planet, sensitive indicators of climate and environmental change, vital recreation areas for an increasingly urbanized world population, sacred places in many cultures and religions and uniquely privileged regions for protected areas, but also sites of erosion, risks and disasters with damaging effects on adjacent lowlands. Based on this new understanding, the UN General Assembly decided on 10 November 1998 that the year 2002 should be the 'International Year of the Mountains', the same year as the World Summit on Sustainable Development in 
Johannesburg. These developments greatly increased public awareness of the effects of climate change and globalization even for remote mountain regions.

In 11 March 2010, the UN General Assembly passed Resolution 64/205 on 'Sustainable Mountain Development'. Its 45 paragraphs include numerous references to common goods of the mountains, common concerns, as well as recommendations for governments and research. In 2012, ten years after the International Year of the Mountains, the conference Rio+20 (Stockholm+40) will be held again in Rio de Janeiro.

\begin{tabular}{|c|c|c|c|c|}
\hline $\begin{array}{l}\text { Raseareh } \\
\text { Werworks }\end{array}$ & $\begin{array}{l}\text { Mountain } \\
\text { Forum }\end{array}$ & & $\begin{array}{l}\text { Mountain Mountain } \\
\text { Research Partnership } \\
\text { Initiative (FAO) }\end{array}$ & \\
\hline $\begin{array}{l}\text { Political } \\
\text { Convertions }\end{array}$ & $\begin{array}{c}\text { Alpine } \\
\text { Convention }\end{array}$ & & & $\begin{array}{l}\text { Carpathian } \\
\text { Convention }\end{array}$ \\
\hline $\begin{array}{l}\text { Poififcel } \\
\text { Declarations: }\end{array}$ & $\begin{array}{l}\text { Chapter } 13 \\
\text { of the } \\
\text { Agenda } 21\end{array}$ & $\begin{array}{l}\text { Evaluation } \\
\text { of the } \\
\text { Agenda } 21\end{array}$ & $\begin{array}{l}\text { International } \\
\text { Year of the } \\
\text { Mountains }\end{array}$ & $\begin{array}{cc}\text { U.N } & \text { Rio }+20 \\
\text { Resolution and } \\
64 / 205 \text { IYM }+10\end{array}$ \\
\hline $\begin{array}{c}\text { African } \\
\text { ICIMOD Mountain } \\
\text { Association }\end{array}$ & $\begin{array}{l}\text { Andean } \\
\text { Mountain } \\
\text { Association }\end{array}$ & & & $\begin{array}{r}\text { Regional Moumtain } \\
\text { Associations }\end{array}$ \\
\hline 1984 & 1992 & 1996 & 2000 & 2008 \\
\hline
\end{tabular}

Fig. 1. The rise of mountain research within the framework of regional associations, political declarations and conventions and research networks (graphic design: K. Heinrich 2011)

This brief summary shows how mountain regions are attracting growing political attention. It also shows that the complex structures, processes and problems of mountain regions can only be tackled successfully on the basis of an inter- and transdisciplinary approach.

In order to strengthen mountain research, to profit from regional expertise and scientific results, to allow comparative analyses, to improve the lives of mountain people and to respond to the challenges of global change, mountain scientists have established mountain research, information and cooperation networks such as the Mountain Forum, the Mountain Partnership and the Mountain Research Initiative (Fig. 1). These in turn encouraged the formation of regional networks like Science for the Carpathians (S4C) and South Eastern European Mountain Research Network (SEEmore) (Borsdorf \& Braun, 2008). While these networks are open for any initiative, the GLORIA network with over 90 research sites on summits in all major mountain ranges of the world focuses on monitoring climate change effects on mountain biodiversity (Grabherr et al., 2010).

In Innsbruck, the Research Focus Alpine Research, the Institute for Mountain Research: Man and Environment and, since 2010, the K1 alpS Centre for Climate Change Adaptation Technologies (in mountain regions) are collaborating within the "Innsbruck Mountain Competence" (see Borsdorf et al., 2010).

\section{Climate change in the Alps}

The Alps are among the most intensely studied mountain regions on earth. This is also true of fast changing weather and climate parameters such as air temperature, humidity, pressure, wind, precipitation and sunshine hours. While 'weather' denotes a snapshot of the 
state of the atmosphere (timescale: minutes to days), 'climate' describes a median state of the atmosphere in a place on a timescale of at least three decades.

For the Alpine Space not only a large number of time series are available but also long timeseries data, which are vital for analysing long-term trends and changes in frequency distributions. Instrumental records, i.e. recorded time series of meteorological and climatological parameters, go back more than 200 years. In the Alps, there is excellent additional information available on former climate states from so-called proxy data, such as speleothems, lake sediments and dendrochronology.

\subsection{Instrumental period}

For the Alps, the longest time series of the meteorological parameters air temperature and air pressure go back to the year 1760. Precipitation records started in 1800, those for cloudiness in the 1840s and sunshine duration records in the 1880s. Within the HISTALP project, records from 577 stations in the Greater Alpine Region $\left(4-19^{\circ} \mathrm{E}, 43-49^{\circ} \mathrm{N}, 0-3500 \mathrm{~m}\right.$ a.s.l.) were homogenized to account for changes in the location, method or instruments for measuring the parameters (Auer et al., 2007). The time series are available as station mode or gridded data and show an incremental increase in air temperature of $+1.2^{\circ} \mathrm{C}$ for the 20 th century. A first peak occurred at the end of the 1940s, the second increase started in the 1970 s $\left(1.3^{\circ} \mathrm{C}\right.$ per 25 years). Calculated over several decades, the temperature trends are the same for all regions of the Alps. Nor are there significant differences between valley and summit stations. Overall, warming in the Greater Alpine Region has been twice as strong as the global mean. On a local/regional scale, however, short-term variabilities have been observed that are stronger than long-term trends (Böhm, 2008). Prominent examples of such short-term and localized deviations would be the extremely warm summer of 2003 or the high-precipitation winter of 1999 with its avalanche disasters. By themselves, such occurrences do not say anything about a change in climate, since they could, in principle, occur in any climate, if only very rarely.

Precipitation shows regionally differing long-term trends. While precipitation in the northeastern part of the Alpine Arc is increasing by $10-15 \%$ per century, it is decreasing by the same percentage in the south-east. However, a short-term variability of $\pm 50 \%$ must be superimposed on these trends and dominates them.

As regards possible future climate changes, we must assume a statistical change in the distribution of individual events (extremes and mean), which is important for several applications:

- agriculture: the number of frost days or the duration and frequency of droughts,

- flood calculation: extreme precipitation,

- calculation of avalanche protection measures, calculation of roof loads: snow depths,

- $\quad$ water management: runoff, i.e. precipitation, snowmelt, glacier runoff.

Currently it is not possible to predict how these and other relevant parameters will change with future climate change as the models return widely differing results. Böhm (2008) considers the following scenarios as well founded: a rise in temperature by $3^{\circ} \mathrm{C}$ (IPCC Scenario A1B) by the year 2100, more frequent positive temperature extremes, no change in storm occurrences in the Alps, a decrease in solid precipitation as well as a reduction in glacier area. Clear scientific pronouncements on other climate parameters are not feasible, especially on convective precipitation (thunderstorms, hail), which is notoriously difficult to capture in numerical models. This is also true of future precipitation events as the relevant models differ widely (Christensen et al., 2007). 


\subsection{Proxy data and historical records}

Proxy parameters are very useful for understanding past climate changes better (Jansen et al., 2007) and they improve the accuracy of predictions for future climate scenarios. They provide information on the climate prior to the start of instrumental records. Tree rings, lake cores, moraines and speleothems show a statistical relation to means of climatological parameters for a given period. This connection stems from processes such as tree growth or dripstone formation, which are controlled by complicated chemical or biological mechanisms that are themselves statistically related to climate parameters.

Dendrochronological dating of Pinus cembra pieces, for instance, provides important climate information for the Alps, Alpine glacier dynamics and shifts in the tree line during the Holocene (Büntgen et al., 2005; Joerin et al., 2008; Nicolussi et al., 2005). Statements on climate change deduced from lake sediments go even further back in time. The layering of the sediments itself can yield information on the climate but also the activity of the biota living in those sediments (Ilyashuk et al., 2011; Schmidt et al., 2006).

A large number of written records on the climate of the past exist for the Alps, particularly on extreme events and climate parameters relating to tax-relevant aspects like harvests. Fliri (1998) and Jäger (2010) have put together an exemplary collection for Tyrol. These reports create an impressive insight into past climate change effects on human spheres of settlement and interest.

\subsection{Climate change and cryosphere}

Cryosphere means the frozen parts of the hydrosphere. In the Alps, these are the glaciers, seasonal snow cover as well as the ice in permafrost and ice caves.

Early studies of glaciers were triggered by catastrophic bursts of glacier lakes in the course of a cooling climate around the year 1600 (Nicolussi, 1990). From the middle of the 19th century, we find systematic investigations of Alpine glaciers (e.g. Schlagintweit \& Schlagintweit, 1850). From around 1890, changes in the length of the glaciers were recorded annually (Patzelt, 1970); in the second half of the 20th century, scientists measured glacier mass balances in the Alps (Fischer, 2011), which were collected by the World Glacier Monitoring Service in Zurich. A global summary of changes in the cryosphere in general and the mountain glaciers in particular is included in the IPCC report (Lemke et al., 2007).

From their peak during the Little Ice Age around the middle of the 19th century, the glaciers of the Austrian Alps have lost circa 50\% of their area (Gross, 1987). The changes in glacier area are documented by country in glacier inventories (Abermann et al., 2009; Lambrecht \& Kuhn, 2007) largely based on remote sensing methods (Haeberli et al., 2007). After the last glacier-friendly period so far in the 1980s, which saw glacier advances, we can now observe an intensified retreat of Alpine glaciers. Related phenomena, such as the formation of supraand peri-glacial lakes require new strategies in glacier monitoring (Paul et al., 2007) and trigger research on basic mechanisms (Huss et al., 2007).

By studying long glaciological time series we obtain base lines for interpreting past climate in high mountain areas where only few direct recordings of weather stations are available (Fischer, 2010; Vincent et al., 2004). Recent comparisons of glacier and climate data led to the development of models that allow an interpretation of glacier stands from the Holocene, documented by moraines, to extrapolate the climate of the time (e.g. Kerschner \& Ivy-Ochs, 2008). Figures 2 and 3 illustrate the dramatic retreat of the Schlatenkees glacier, municipality of Matrei, East Tyrol. 


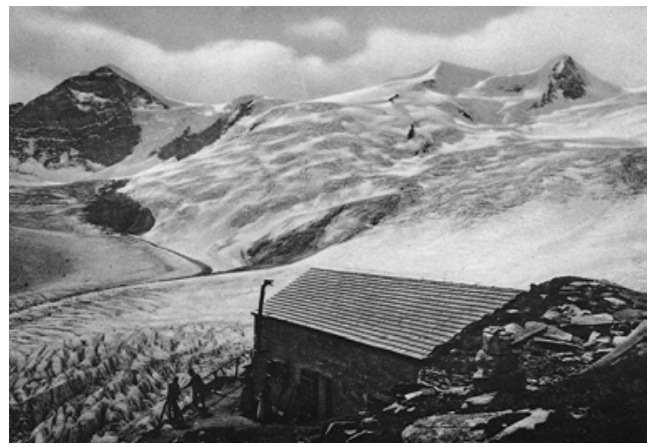

Fig. 2. Schlatenkees 1890 (Photograph: V. Sella)

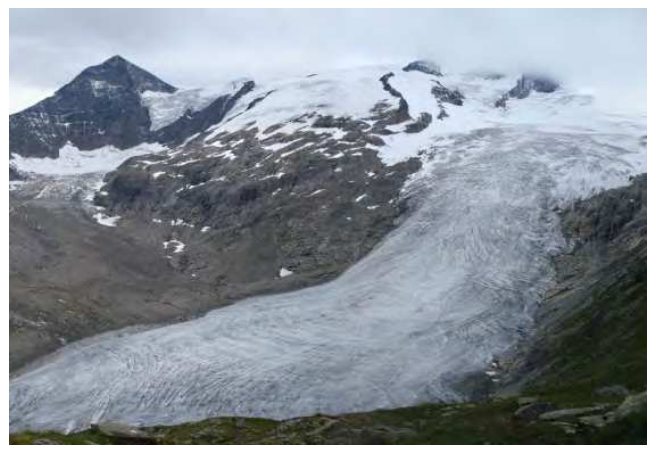

Fig. 3. Schlatenkees 2010 (Photograph: A. Fischer)

Alpine permafrost in general and permafrost in the Alps in particular, is a phenomenon that has only been known and scientifically investigated for a short time (Barsch, 1969). Concrete pronouncements on its extent are therefore still relatively imprecise (e.g. Harris et al., 2001; Krainer et al., 2007). What we know about the large-scale distribution of permafrost in the Alps stems from the Swiss Alps. Barsch (1978) puts the volume of permafrost in the Western Alps at 5-10 $\mathrm{km}^{3}$. Haeberli (1975) suggests that permafrost can be assumed for areas above $2200 \mathrm{~m}$ a.s.l, above $2550 \mathrm{~m}$ a.s.l. permafrost is likely at the foot of slopes with a northern exposition and above $3000 \mathrm{~m}$ a.s.l. on steep south-facing slopes (Keller, 1987). Such statements are either based on morphological analyses of block glaciers as the most pronounced form of Alpine permafrost or, more recently, on modelling approaches using the energy balance in a simplified way as indicator for the existence of mountain permafrost (Hoelzle et al., 2001). For rock glaciers in Alto Adige, scientists were able to show clearly how active block glaciers have become inactive with loss of the ice from the middle of the 19th century (Stötter, 1994). Unlike the robust climate indicators of glaciers and permafrost, the seasonal snow cover is subject to large interannual fluctuations. If you take a series of studies on the duration and thickness of snow cover within the Alpine Space (Beniston, 1997) no homogenous picture emerges, unlike the results of other surveys in the northern hemisphere (e.g. Lemke et al., 2007). Given the regionally differentiated precipitation trends, confirmed by HISTALP data, this is hardly surprising. From a climatological perspective, it can be said that even in a tendentially warmer climate, winters with large amounts of snow 
will continue to occur, just as during a cooler climate there were some winters with little snow (Beniston, 2011; Jäger, 2010).

\subsection{Climate change and natural hazards}

Since climate and weather drive many Alpine natural hazards, it is hardly surprising to find scientists everywhere debating this issue of how natural hazards behave under conditions of climate change. In this context, we must distinguish between the medium- to long-term temporal dimension of the climate, which establishes the framework of a longer-term disposition, and the short-term dimension of weather conditions, which may trigger natural hazard events. If we look at it using a time-frame of decades, the impact of global warming for natural hazard processes takes priority, while a look at what triggers processes shows that changes in precipitation patterns are decisive.

In the course of rising temperatures, ice in permafrost melts. Together with shrinking glaciers, this means that the stabilizing effect of ice, both as ice cement in the substratum and as protective ice shield on the surface, is shifting to ever higher altitudes. At the same time, this process makes more and more unconsolidated sediment available for erosion. In its wake, tension fissures not only become more frequent but they also occur at higher altitudes (Stötter et al., 1996) and gravitational (rock) fall from over-steep walls also increases in frequency (Stötter, 2007). Add to this general development of disposition, which can be recorded reliably, a changed pattern of precipitation intensity as trigger, which cannot be statistically proven to date.

One interesting clue of a change in precipitation towards more intense precipitation events stems from the analysis of the flood events in the Alps during the last two decades and, on a larger spatial scale, in Central Europe. Since the 1990s, an increase in extreme events has been recorded in several river systems, with return periods of 100 years and more, which show a probability of recurrence in such short succession of $p<0.001$ (Table 1).

\begin{tabular}{|c|c|c|c|c|}
\hline River & \multicolumn{3}{|c|}{ Years of flood events } & Return period (yrs.) \\
\hline Rhine & 1993 & 1995 & & 3300 \\
\hline Danube & 1999 & 2002 & & 2700 \\
\hline Elbe & 2002 & 2006 & & 1000 \\
\hline Bregenzer Ache & 1999 & 2002 & 2005 & 29000 \\
\hline Lech & 1999 & (2002) & 2005 & ? \\
\hline
\end{tabular}

Table 1. Return period of cumulative large flood events on Central European rivers (Stötter et al., 2009)

Such mass occurrences of large events go hand in hand with equally large, and rising, damages. Here another aspect comes into play that not only explains but also drives the increase of risk. Since the middle of the 20th century, Tyrol, for example, has experienced a dramatic spatial expansion of settlement, commercial and transport infrastructure areas, driven by the shift from a predominantly agrarian society to a service society shaped by tourism. The number of exposed assets has risen in parallel with this development and can 
be read off key indicators such as increase in population, number of buildings, visitor beds and buildings used in tourism (Table 2). In sum, we can say that while changes in the risk of natural hazards show a clear correlation to climate change, they are possibly driven much more by socio-economic changes.

\begin{tabular}{|l|c|}
\hline Indicator & Change factor \\
\hline resident population & 1.73 \\
\hline visitor beds & 7.20 \\
\hline residential buildings & 5.10 \\
\hline visitor accomm. buildings & 6.12 \\
\hline
\end{tabular}

Table 2. Change factor of key elements for damage potential in the period of 1951-2001 for Tyrol (Stötter, 2007)

\section{Socio-economic change}

\subsection{Population and settlements}

For centuries, population density in the Alps was roughly equivalent to the European average. With the beginning of industrialization, massive migration from the rural regions of the Alps set in (Bätzing, 2003). This so-called 'flight from the mountains' started in the French Alps and spread unevenly to other Alpine regions at different times and in varying intensity. At the end of the 20th century, significant depopulation still occurred in the Italian and, to a lesser degree, the east-Austrian part of the Alps. As it is mostly the young population who was and still is leaving the Alpine Space, such migration losses cannot be compensated for by a surplus of births and result in an overall decline in the number of inhabitants.

Current demographic change throughout Europe is characterized by lower fertility, increasing old-age overhang and mortality (second demographic transition). Apart from a few regions in the northern Alps (including Western Austria), current natural population growth in the Alpine Space is negative (cf. Tappeiner et al., 2008). Inter- and intraregional migration now make up the strongest component of population development, further deepening the spatial disparities between active and passive regions and between urban agglomerations and peripheral rural spaces (cf. Bätzing 2003; Tappeiner et al., 2008). Within the densely populated areas, this development is differentiated by sub- and postsuburbanizing processes (Fig. 4 and 5). Along the main valleys (e.g. the lower Inn valley in Tyrol) these processes have encouraged the formation of bands of settlement, commercial and transport infrastructure areas. Add to this urbanization processes along the Alpine fringe in the catchment of large extra-Alpine metropoles and in the inner-Alpine tourist centres (e.g. Chamonix, Davos, Kitzbühel) (Bätzing, 2003; cf. Tappeiner et al., 2008). Such developments result from changing preferences in establishing main and additional domiciles (amenity migration) and a greater reach in travel to work and to holiday homes (Perlik, 1999). In the main valleys and tourist centres on the Alpine fringe, settlement space is getting scarce, building land prices are rising and building coverage is becoming very compact (Bender, 2005). This is contrasted in peripheral areas with shrinking 
municipalities - all the way to complete desertion of villages in the Southern Alps - that find it ever harder to cover the costs of maintaining their infrastructure.
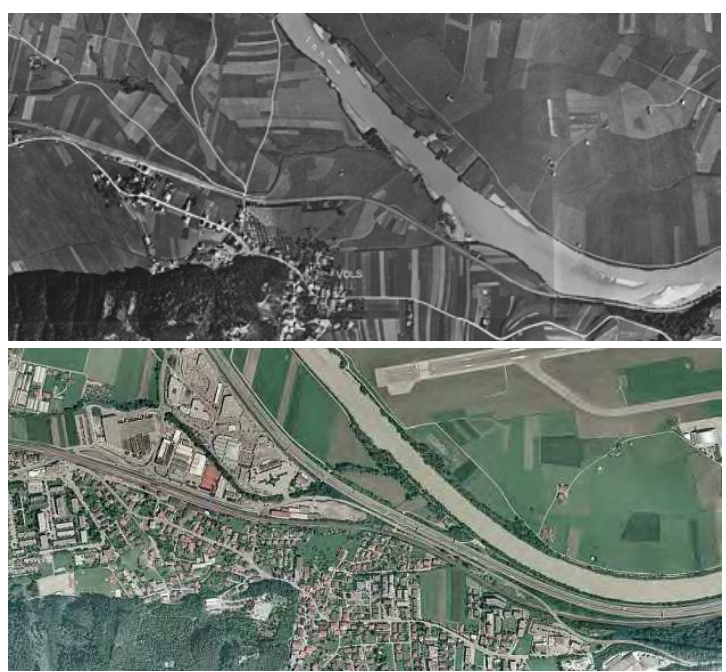

Fig. 4. and 5. Post-suburbanization in the municipality of Völs (along the Inn valley near Innsbruck, Tyrol) between 1940 and 2005 (Source: Orthoimages, Land Tirol, Scale 1:10,000)

As a result of climate change, the inhabitants of valleys and basins will increasingly suffer from unfavourable local climate conditions. These can be mitigated through suitable architectural and urban planning measures, such as high energy-efficiency of buildings, avoiding islands of warmth, keeping fresh air corridors open, landscaping and water retention. Such measures, however, will be hampered by the trend towards further densification of settlements, as communities run out of available building land and transport policy favours compact settlements. The required constructional measures represent not just an adaptation to climate change but are also aimed at lessening it (Hiess, 2010b; Kronberger et al., 2010; Wyss \& Arlanch, 2009).

\subsection{Agriculture and forestry}

Ever since subsistence farming was abandoned, agriculture in the Alps has been dominated by grassland farming, including the special case of Almwirtschaft, a seasonal expansion of pastures into the subalpine altitudinal zone, which continues to this day. Arable farming, market gardening as well as fruit and wine growing (the latter in the Austrian Alps only in very small areas) only happens in the valleys and basins these days.

Given the difficult conditions of climate and terrain, mountain agriculture is becoming less and less competitive. In large parts of the Alps, this leads to the increasing abandonment of farms and marginal areas. In the Italian Alps in particular, we can observe a pronounced decline, while in the northern, German-speaking, Alpine countries and especially in Austria such processes are rare (cf. Borsdorf, 2005). Here, the agrarian cultural landscape has largely been retained, even if it has been adapted in many places to allow modern utilization (cf. Tyrolean Cultural Landscape Inventory; Land Tirol, n.d.). This is linked to the mountain farming subsidies, which started several decades ago, but also to the fact that Austrian 
mountain farms are mostly run as a part-time concern, i.e. in combination with other economic activities, mainly in tourism. Moreover, agricultural production, especially in the Alps, has been oriented to high quality products, viz. the high proportion of organic farming and regional origin certified products (Bender, 2010).

Climate change affects Alpine agriculture in positive and negative ways. Negative impacts include reduced yield or quality and declining yield security as a result of the likely increase in summer drought, plus a possible increase in extreme events such as heavy rain, storms and hail. Arable farming, fruit and wine growing can adapt to these problems by choosing less vulnerable varieties. While grassland in regions with up to $800 \mathrm{~mm}$ annual precipitation is likely to experience severe reductions in yield, higher areas with more than $800 \mathrm{~mm}$ precipitation can expect a rise in production potential (Kronberger et al., 2010), which benefits mountain grassland farming.

As agricultural subsidies strongly influence profitability and land-use distribution, a possible - and repeatedly discussed - reduction or reorientation of such subsidies would lead to significant changes. The effects of climate change are therefore going to be mainly noticed with crops that are less affected by EU market regulations. These include mainly wine and fruit growing, which also benefit from longer vegetation periods at higher altitudes, always presuming that irrigation in fruit growing can be guaranteed. For North and South Tyrol, farmers already assume a significant expansion of fruit growing areas at the expense of arable and grasslands (Fig. 6). It is impossible to predict whether total yields in Alpine agriculture will improve or decline as a result of climate change as there are too many parameters influencing results (warmth, dryness, pests, etc.).

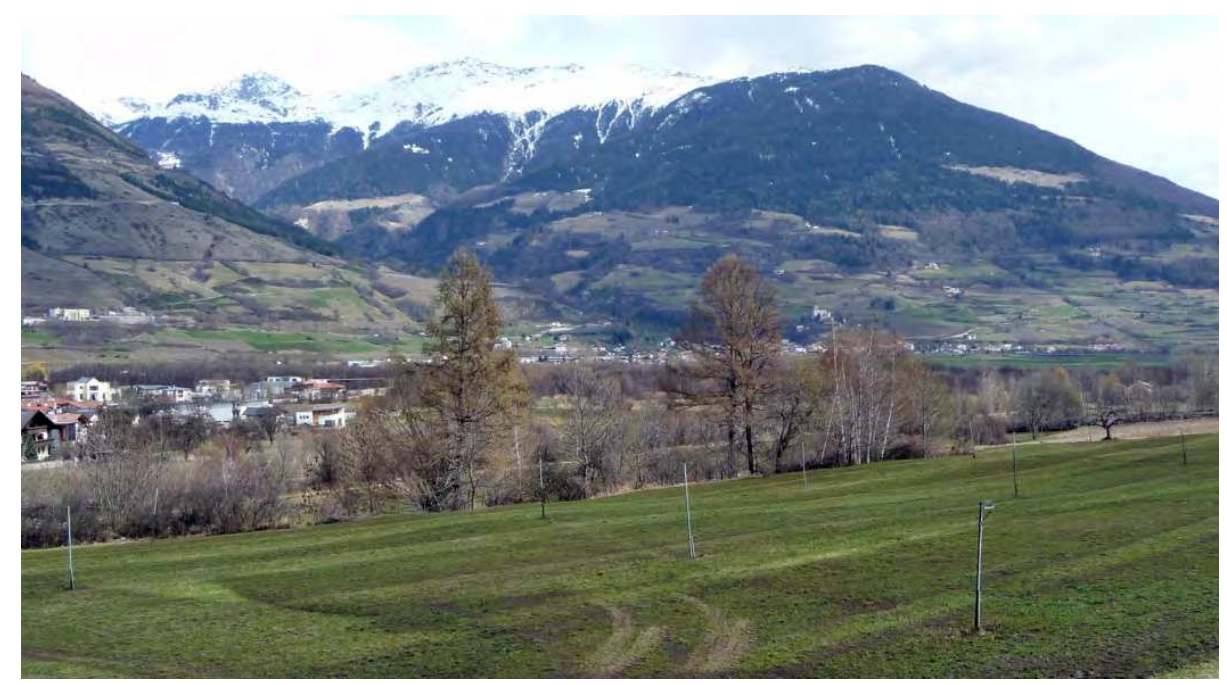

Fig. 6. Designated fruit growing area near Glurns, Upper Vinschgau (South Tyrol). On the field in the foreground, irrigation equipment, indispensible for fruit growing in this area, has already been installed (Photograph: O. Bender 2011)

Despite the relatively stabile situation of agriculture in Austria as compared to that of southern Alpine countries, recent decades did see considerable losses of cultural landscapes, leading to an expansion of wooded areas, particularly in steep mid-slope areas of the 
montane zone. Figures from the cadastre show that in the 1990s alone the wooded area increased by 5.5\% (Borsdorf \& Bender, 2007). Mountain forests fulfil many functions for humans, particularly as protective forests and for timber production, but also as $\mathrm{CO}_{2}$ sinks for climate protection. Forestry is increasingly making an effort to plant mixed forests suited to the individual location with varieties adapted to climate change. In the past, particularly near ore and salt processing sites in eastern Austria, fast growing fir trees were planted as monocultures. These are now being replaced by mixed forests. In many places, mountain forests are exposed not just to climate stress but also to additional factors such as game damage, immissions, pests, etc., which further increase the vulnerability of forest ecosystems to climate change. Overall, forestry in the Austrian Alps must be considered highly vulnerable to changes in climate (Kronberger et al., 2010).

At higher altitudes, more extensive mountain pasturing basically encourages a rise in the forest line, which has been held down artificially through grazing on land mostly cleared by burning. There are as yet no clear indications of tree stands rising solely as a result of changes in climate (cf. Nicolussi et al., 2005; Wieser et al., 2009; Fig. 7 and 8). The ecological conditions in the treeline ecotone are too complex and the response times of subalpine forest communities too long to draw direct conclusions (Borsdorf \& Bender, 2007).
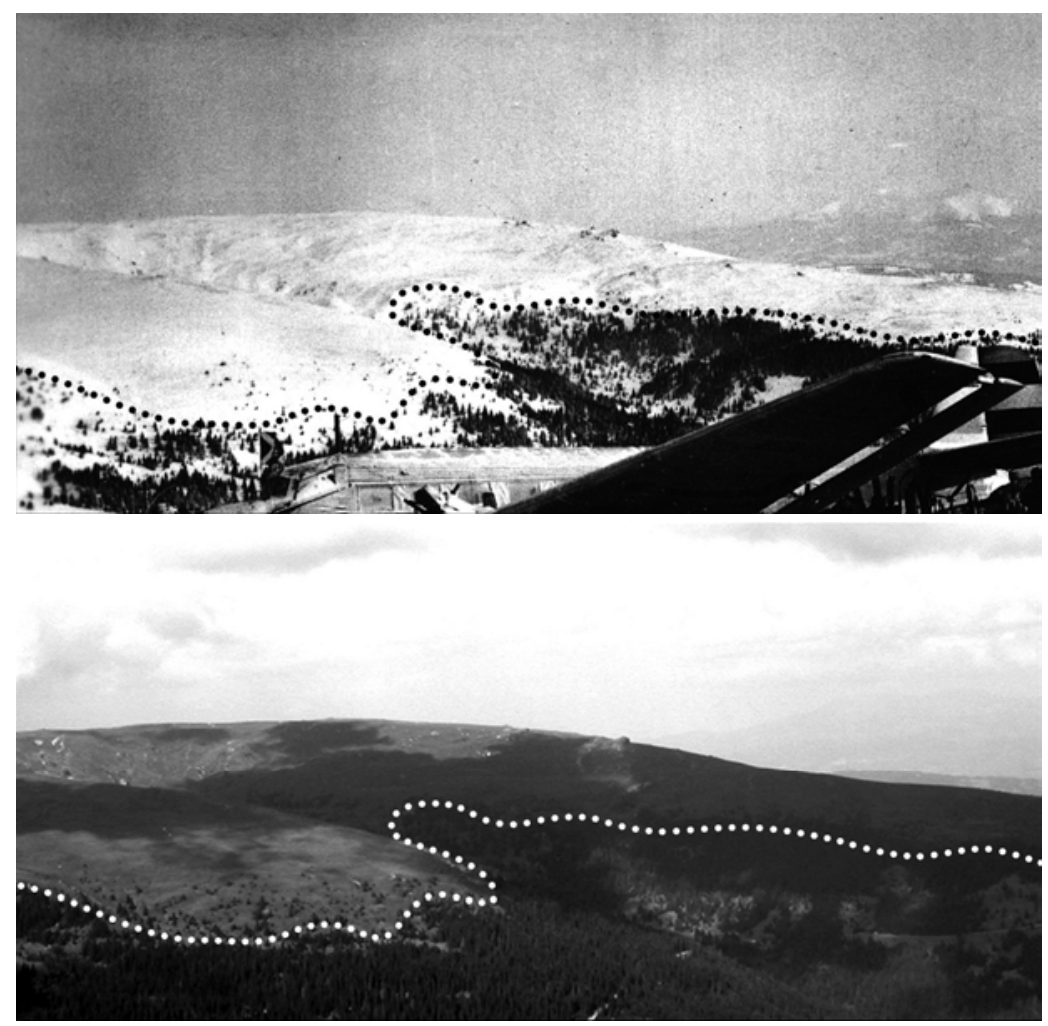

Fig. 7. and 8. Eastern flank of Koralpe in 1936 and 2004. The dotted line shows the current forest line (Source: Stützer, 2005) 


\subsection{Traffic and tourism}

Within the European economic area, the Alps represent an obstacle to traffic. Since prehistoric times, this obstacle has had to be overcome by transit routes along the large cross valleys and across the passes. Since the end of the 18th century, these routes have been repeatedly expanded for roads and railways in response to increasing traffic flows. The large valleys have definitely benefitted from this transit traffic, but at the same time they are increasingly suffering from the accompanying environmental burdens (air pollution, noise, land grab and dissection of the landscape). The total traffic volume must be broken down into transit traffic, import traffic (including incoming tourism) and local traffic (including commuting in the agglomerations) (Permanent Secretariat of the Alpine Convention, 2007). Contrary to the often expressed view at local protest activities against transit traffic, regional indigenous traffic accounts for more than 70\% of total road traffic (Gruber, 1994).

Traffic is today seen as a key driver of climate change. New transport projects that aim to shift traffic from road to rail (like the Brenner Base Tunnel in Tyrol) should also be motivated by the desire to protect the climate, even if, as the traffic breakdown shows, they can only solve a small part of the problem. In the Alps as well, the main focus should be on environment- and climate-friendly solutions to regional and urban traffic as well as on incoming tourism (cf. Hiess, 2010a).

The Alps are among the earliest tourist destinations and from the beginning the focus has been on the landscape. With the advent of mass tourism in the 1960s, tourism and the leisure industry have become a major economic factor in the rural areas of the Alps $(12 \%$ of jobs, $16 \%$ of GDP), albeit with great differences between regions and municipalities (Bätzing, 2003). Within the last thirty years, a long-term trend towards skiing-based winter tourism has emerged for large parts of the Alps, with significantly higher added value than summer tourism. This development goes hand in hand with a knock-out competition between tourist destinations. Only municipalities that invest continuously in their tourism portfolio will be able to achieve growth in the future.

Climate change increasingly threatens winter tourism, at first in lower-lying areas, later on possibly in all tourist destinations. If we assume a temperature rise of $4^{\circ} \mathrm{C}$, only $30 \%$ of winter sports places will be able to guarantee snow (Abegg et al., 2007). This development will, however, be subject to great regional differences. Clear losers in this scenario are the lowerlying skiing areas with pistes not exceeding $2500 \mathrm{~m}$ a.s.l. (Alpine fringe, large parts of the Eastern Alps), while higher destinations with pistes above $3000 \mathrm{~m}$ (glaciated regions of the Western Alps and places in the Central Alps) are in a naturally more favourable position to cope. About two decades ago, municipalities began to mitigate lack of snow by making artificial snow and have come to rely on snow canons more and more (Hahn, 2004; Fig. 9). Artificial snow makes the pistes mechanically more robust and better adapted to developments in skiing equipment and to the rising standards of the visitors. Undoubtedly this must be seen as an example of successful development and implementation of adaptation strategies to the challenges of climate change. According to Steiger (2011), only a significant increase in artificial snow making allows almost all of the 100+ skiing areas in Tyrol and South Tyrol to maintain skiing until the middle of the 21st century if we assume a moderate warming scenario (A1B). At the same time, this form of adaptation is linked to considerable environmental problems (Pröbstl, 2006) and, with rising temperatures, the demand for water and energy will increase further (Olefs et al., 2010). Moreover, it raises the question if rising costs for winter skiing operations can be set off by even higher prices for the tourism portfolio or whether they will have to be met by the public (Abegg 2011; Steiger \& Mayer 2008). 


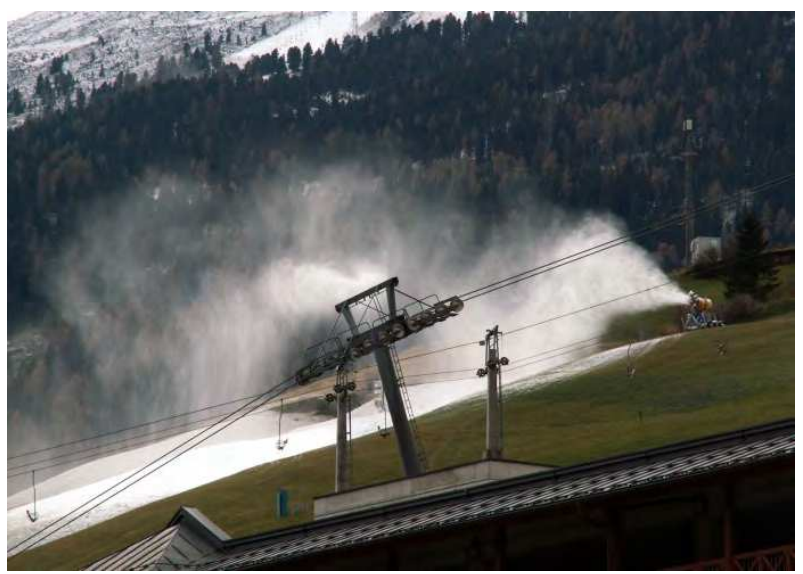

Fig. 9. Snow-making with snow canons in Obergurgl, Tyrol (Photograph: A. Borsdorf 2005)

Summer and all year skiing areas on glaciers, established in the 1960s and 1970s, today operate almost exclusively from autumn to spring and no longer in summer as a result of glacier shrinkage (Fischer et al., 2011; Smiraglia et al., 2008). As regards tourist infrastructure (lift stations and pylons), glacier melt has been very effectively delayed by covering smaller areas with fleece to extend the maintenance intervals (Olefs \& Fischer, 2008). For Alpine summer tourism, negative as well as positive effects can be deduced from regional climate scenarios. Negative effects include changes in the landscape, melting glaciers, thawing permafrost, drought and water scarcity as well as a potential increase in the risk of natural hazards (Abegg, 2011). Alpine walking and climbing routes will be ever more difficult to secure under these conditions. Overall, however, there is the chance of a revival of Alpine summer tourism (classic summer holiday) because the areas outside the Alps, where most tourists come from, and the Mediterranean competition destinations could well be much harder hit by global warming in the form of heat waves, water shortages, forest and bush fires, dying bathing lakes and rivers (cf. Bourdeau, 2008). If they want to take advantage of such a scenario, Alpine destinations must diversify away from a narrow orientation on winter sports and towards sustainable tourism. For such a transition to be handled successfully, it is vital to create the right awareness (Kronberger et al., 2010). This will take new communication strategies as well as comprehensive participatory processes involving all stakeholders as well as tourist operators and tourists themselves.

\section{Conclusion}

Mountain research started early with some Arab scientists and in Europe with Marco Polo and Christopher Columbus. The latter was fascinated by the mountains he observed in the New World and refers to them repeatedly in his work. Mathieu (2011) sees this work as a nodal point for mountain research that continued with the questionnaires of Felipe II which include six questions about mountains. The French geographer Philippe Buache was the first who drew a map that showed the mountains of the world as a cohesive system. Alexander von Humboldt provided another important impulse analysing the nature and hypsographic zones of the Andean Cordillera. With the rise of sciences in the 19th and 20th century, the Alps gradually became the most intensely investigated mountain range of the 
world. However, the Alpine experience has to be seen in the light of comparison with other mountain ranges. Carl Troll based his research in the Andes, the Himalaya and the Alps.

This is why the example of the Alps covered in this chapter has to be seen in a global context. Climate change and globalization are world-wide phenomena and they meet fragile ecosystems and traditional societies and economies ill prepared for the impacts of these global processes. It cannot be the purpose of this chapter to make a detailed comparison, but it is quite clear that effects observed in the Alps may be even more drastic in mountain regions located in a socio-economic environment less well equipped to find and implement adaptations strategies.

As the examples from the Alps show, climate change and globalization meet complex manenvironment systems in mountain regions. Glacier and permafrost retreat, water scarcity, soil erosion and land-use change, as well as loss of biodiversity are consequences of climate change on the regional scale of the mountain area. Climate change thus impacts on ecosystem services, not just for the societies in the mountains but also for the inhabitants of the adjacent lowlands. Globalization processes also exert an ever faster impact on ecosystems. Even more dramatic is their effect on the cultural landscape, on agriculture, population structure, mobility, as well as the urbanization and marginalization of peripheral mountain regions. Societies are affected in socio-economic, political and institutional terms and require decision making at regional and local level. Both subsystems interact in the sphere of land use and land management (Fig. 10).

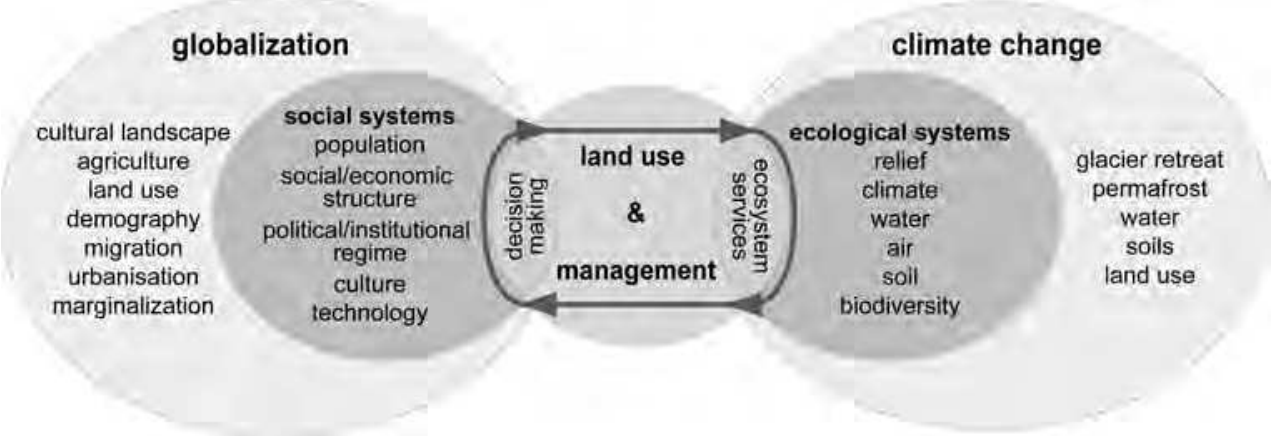

Fig. 10. Man-environment system in mountain regions (modified from: IGBP, 2005)

Since Global Change affects man-environment systems with greatly varying intensity and speed in different mountain regions, comprehensive long-term observation and monitoring programmes are necessary to capture it. One such programme is the global GLORIA initiative with its high-mountain ecology monitoring instruments (Grabherr et al., 2010; Pauli et al., 2007). It is not enough to study individual system elements of the natural- and the anthroposphere (single discipline approach) or the interaction between subsystems or even the entire man-environment system (interdisciplinary approach). When all is said and done, such analyses are always restricted to the production of system knowledge.

The challenges of climate change and globalization increasingly call for target knowledge to be provided to decision makers in politics and the economy. Everybody uses key terms such as sustainability, preserving biodiversity, safeguarding ecosystem services, disaster protection, establishing protected areas, ensuring economic capability, competitiveness and social coherence as things to strive for. These are the expression of a heightened awareness of social 
and political responsibility, but as a rule they are not very specific and their implementation is not without conflict. Therefore it is vital to include stakeholders, not only in the creation of system knowledge but even more importantly in the assessment and transformation into target knowledge in truly transdisciplinary style. The mountain.TRIP project is making a valuable contribution to the dissemination of system and target knowledge to a variety of recipients (stakeholders and general populace) by facilitating the sharing of insights (Braun, 2010). Another important aspect is creating and disseminating management knowledge at different levels and across different regions. The DIAMONT project produced exemplary databases on steering instruments and best practices (Borsdorf et al., 2010).

Tourist advertising may talk about 'time standing still' but global climate change and globalization have triggered dramatic changes in the Alps that can be made visible using the indicators mentioned. In the cultural landscape, persistent structures used to be at work for a long time, but the process that has its roots in the beginnings of industrialization is forcing accelerating dynamics onto them, speeded up further in recent decades as a result of globalization.

Within the cultural space of the Alps, social and economic impact factors may dominate (cf. Slaymaker, 2001), but with each 'warm' year it becomes clearer that climate factors are gaining in significance. Climate change determines tourism just as much as the growth options for settlements and commercial areas, what is and is not a secure road and the routing of new roads and rail tracks. We may not yet perceive the full extent of this impact, yet the consequences are real and ever more significant. There is much to research!

\section{References}

Abegg, B. (2011). Tourismus im Klimawandel. CIPRA, Available from: http://www.cipra.org/pdfs/964_de/at_download/file

Abegg, B., Agrawala, S., Crick, F. \& de Montfalcon, A. (2007). Climate change impacts and adaptation in winter tourism, In: Climate change in the European Alps: Adapting winter tourism and natural hazards management, Agrawala, S., pp. 25-60, OECD, ISBN 978-92-64-03168-5, Paris

Abermann, J., Lambrecht, A., Fischer, A. \& Kuhn, M. (2009). Quantifying changes and trends in glacier area and volume in the Austrian Ötztal Alps (1969-1997-2006). The Cryosphere, Vol. 3, No. 2, (October 2009), pp. 205-215, ISSN 1994-0416

Auer, I., Böhm, R., Jurkovic, A., Lipa, W., Orlik, A., Potzmann, R., Schöner, W., Ungersböck, M., Matulla, C., Briffa, K., Jones, P.D., Efthymiadis, D., Brunetti, M., Nanni, T., Maugeri, M., Mercalli, L., Mestre, O., Moisselin, J.-M., Begert, M., MüllerWestermeier, G., Kveton, V., Bochnicek, O., Stastny, P., Lapin, M., Szalai, S., Szentimrey, T., Cegnar, T., Dolinar, M., Gajic-Capka, M., Zaninovic, K., Majstorovic, Z. \& Nieplova, E. (2007). HISTALP - historical instrumental climatological surface time series of the Greater Alpine Region. International Journal of Climatology, Vol. 27, No. 1, (January 2007), pp. 17-46, ISSN 1097-0088

Barsch, D. (1969). Permafrost in der oberen subnivalen Stufe der Alpen. Geographica Helvetica, Vol. 24, No. 1, pp. 10-12, ISSN 0016-7312

Barsch, D. (1978). Active rock glaciers as indicators tor discontinuous alpine permafrost - an example from the Swiss Alps, Proceedings of the Third International Conference on Permafrost, Vol. 1, pp. 348-353, ISBN 0-660-01735-0, Edmonton, July 1978 
Bätzing, W. (2003). Die Alpen. Geschichte und Zukunft einer europäischen Kulturlandschaft (2nd edition), Beck, ISBN 978-3-406-50185-0, München

Bender, O. (2005). Verdichtung oder Zersiedlung? Regionale Unterschiede in der Bautätigkeit und Siedlungsdynamik, In: Das neue Bild Österreichs. Strukturen und Entwicklungen im Alpenraum und den Vorländern, Borsdorf, A., pp. 122-123, ÖAW, ISBN 978-3-7001-3513-0, Wien

Bender, O. (2010). Entstehung, Entwicklung und Ende der alpinen Bergbauernkultur, In: Über das Entstehen und die Endlichkeit physischer Prozesse, biologischer Arten und menschlicher Kulturen, Heller, H., pp. 113-137, ISBN 978-3-643-50229-2, Wien, Berlin

Beniston, M. (1997). Variations of snow depth and duration in the Swiss Alps over the last 50 years: links to changes in large-scale climatic forcings. Climatic Change, Vol. 36, No. 3-4, (July 1997), pp. 281-300, ISSN 0165-0009

Beniston, M., Uhlmann, B., Goyette, S. \& Lopez-Moreno, J.I. (2011). Will snow-abundant winters still exist in the Swiss Alps in an enhanced greenhouse climate? International Journal of Climatology, Vol. 31, doi: 10.1002/joc.2151, ISSN 0899-8418

Böhm, R. (2008). Harte und weiche Fakten zum Klimawandel. Sachverständige, Vol. 32, No. 4, pp. 170-177, ISSN 2075-3586

Borsdorf, A. (Ed.). (2005). Das neue Bild Österreichs. Strukturen und Entwicklungen im Alpenraum und den Vorländern, ÖAW, ISBN 978-3-7001-3513-0, Wien

Borsdorf, A. \& Bender, O. (2007). Kulturlandschaftsverlust durch Verbuschung und Verwaldung im subalpinen und hochmontanen Höhenstockwerk: Die Folgen des klimatischen und sozioökonomischen Wandels, In: Alpine Kulturlandschaft im Wandel. Hugo Penz zum 65. Geburtstag, Innsbrucker Geographische Gesellschaft, pp. 29-50, ISBN 978-3-901182-86-0, Innsbruck

Borsdorf, A. \& Braun V. (2008). The European and Global Dimension of Mountain Research An Overview. Revue de Géographie Alpine, Vol. 96, No. 4, pp. 117-129, ISSN 1760-7426

Borsdorf, A., Stötter, J. \& Veuillet, E. (Eds.). (2008). Managing Alpine Future. Proceedings of the Innsbruck Conference October 15-17, 2007, ÖAW, ISBN 978-3-7001-6571-2, Innsbruck

Borsdorf, A., Tappeiner, U. \& Tasser E. (2010). Mapping the Alps. In: Challenges for mountain regions. Tackling Complexity, Borsdorf, A., Grabherr, G., Heinrich, K., Scott, B. \& Stötter, J., pp. 186-191, Böhlau, Vienna

Bourdeau, P. (2008). The Alps in the age of new style tourism: between diversification and post-tourism? In: Managing Alpine Future. Proceedings of the Innsbruck Conference October 15-17, 2007, Borsdorf, A., Stötter, J. \& Veulliet, E., pp. 81-86, ÖAW, ISBN 978-3-7001-6571-2, Innsbruck

Braun, F. (2010). Closing the gap between science and practice. mountain.TRIP - an EU project coordinated by IGF, In: Challenges for mountain regions. Tackling Complexity, Borsdorf, A., Grabherr, G., Heinrich, K., Scott, B. \& Stötter, J., pp. 204-210, Böhlau, ISBN 978-3-205-78652-8, Vienna

Büntgen, U., Tegel, W., Nicolussi, K., McCormick, M., Frank, D., Trouet, V., Kaplan, J.O., Herzig, F., Heussner, K.-U., Wanner, H., Luterbacher, J. \& Esper, J. (2011). 2500 Years of European Climate Variability and Human Susceptibility. Science, Vol. 331, No. 6017, (February 2011), pp. 578-582, ISSN 0036-8075

Christensen, J.H., Hewitson, B., Busuioc, A., Chen, A., Gao, X., Held, I., Jones, R., Kolli, R.K., Kwon, W.-T., Laprise, R., Magaña Rueda, V., Mearns, L., Menéndez, C.G., Räisänen, J., Rinke, A., Sarr A. \& Whetton, P. (2007). Regional Climate Projections, In: Climate Change 2007: The Physical Science Basis. Contribution of Working Group I to 
the Fourth Assessment Report of the Intergovernmental Panel on Climate Change, Solomon, S., Qin, D., Manning, M., Chen, Z., Marquis, M., Averyt, K.B., Tignor M. \& Miller H.L., pp. 847-940, Cambridge University Press, ISBN 978-0-521-88009-1, Cambridge, UK, New York, NY

EEA (Ed.). (2004). Impacts of Europe's changing climate. An indicator-based assessment, European Environment Agency, ISBN 978-92-9167-372-8, Copenhagen

Fischer, A. (2010). Glaciers and climate change: Interpretation of 50 years of direct mass balance of Hintereisferner. Global and Planetary Change, Vol. 71, No. 1-2, (March 2010), pp. 13-26, ISSN 0921-8181

Fischer, A. (2011). Long term glacier monitoring at the LTER test sites Hintereisferner, Kesselwandferner and Jamtalferner and other glaciers in Tyrol. Plant Ecology and Diversity, in press, ISSN 1755-0874

Fischer, A., Olefs, M. \& Abermann, J. (2011). Glaciers, snow and ski tourism in Austria's changing climate. Annals of Glaciology, Vol. 52, No. 58, pp. 89-96, ISSN 0260-3055

Fliri, F. (1998). Naturchronik von Tirol. Tirol, Oberpinzgau, Vorarlberg, Trentino. Wagner, ISBN 3-7030-0313-8, Innsbruck

Grabherr, G., Pauli H. \& Gottfried, M. (2010). A worldwide observation of effects on climate change on mountain ecosystems, In: Challenges for mountain regions. Tackling Complexity, Borsdorf, A., Grabherr, G., Heinrich, K., Scott, B. \& Stötter, J., pp. 48-57, Böhlau, ISBN 978-3-205-78652-8, Vienna

Gross, G. (1987). Der Flächenverlust der Gletscher in Österreich 1850-1920-1969. Zeitschrift für Gletscherkunde und Glazialgeologie, Vol. 23, No. 2, pp. 131-141, ISSN 0044-2836

Gruber, R. (1994). Der Strassen- und Schienenverkehr im Alpenraum. Verkehrsaufkommen und Auswirkungen auf die Umwelt, In: Verkehr in den Alpen: mehr als nur Transit, Belletti, P., Nada, E. \& Pastorelli, F., pp. 9-38, CIPRA Italia, ISBN 3-906521-28-1, Torino

Haeberli, W. (1975). Untersuchungen zur Verbreitung von Permafrost zwischen Flüelapass und Piz Grialetsch. VAW-Mitteilungen, Vol. 17, 182 pp., ISSN 0374-0056

Haeberli, W., Hoelzle, M., Paul, F. \& Zemp, M. (2007). Integrated monitoring of mountain glaciers as key indicators of global climate change: the European Alps. Annals of Glaciology, Vol. 46, No. 1, (October 2007), pp. 150-160, ISSN 0260-3055

Hahn, F. (2004). Künstliche Beschneiung im Alpenraum. CIPRA, Available from: http://www.cipra.org/de/alpmedia/publikationen/2709/

Harris, C., Haeberli, W., Vonder Mühll, D. \& King, L. (2001). Permafrost monitoring in the high mountains of Europe: the PACE Project in its global context. Permafrost and Periglacial Processes, Vol. 12, No. 1, (March 2001), pp. 3-11, ISSN 1099-1530

Hiess, H. (2010a). Transport in climate change. CIPRA, Available from: http://www.cipra.org/pdfs/826_en/at_download/file

Hiess, H. (2010b). Spatial planning in climate change. CIPRA Available from: http://www.cipra.org/pdfs/837_en/at_download/file

Hoelzle, M., Mittaz, C., Etzelmüller, B. \& Haeberli, W. (2001). Surface energy fluxes and distribution models of permafrost in European mountain areas: an overview of current developments. Permafrost and Periglacial Processes, Vol. 12, No. 1, (March 2001), pp. 53-68, ISSN 1099-1530

Huss, M., Bauder, A., Werder, M., Funk, M. \& Hock, R. (2007). Glacier-dammed lake outburst events of Gornersee, Switzerland. Journal of Glaciology, Vol. 53, No. 181, (March 2007), pp. 189-200, ISSN 1727-5652 
IGBP - International Geosphere-Biosphere Programme - Secretariat (Ed.). (2005). Global Land Project: Science Plan and Implementation Strategy. IGBP Report, No. 53/IHDP Report, No. 19, 64 pp., ISSN 0284-8105

Ilyashuk, E.A., Koinig, K.A., Heiri, O., Ilyashuk, B.P. \& Psenner, R. (2011). Holocene temperature variations at a high-altitude site in the Eastern Alps: a chironomid record from Schwarzsee ob Sölden, Austria. Quaternary Science Reviews, Vol. 30, No. 1-2, (January 2011), pp. 176-191, ISSN 0277-3791

Jäger, G. (2010). Schwarzer Himmel - Kalte Erde - Weißer Tod. Eine kleine Agrar- und Klimageschichte von Tirol, Wagner, ISBN 978-3-7030-0476-6, Innsbruck

Jandl, R., Borsdorf, A., van Miegroet, H., Lackner, R. \& Psenner, R. (Eds.). (2009). Global Change and Sustainable Development in Mountain Regions. COST Strategic Workshop, Innsbruck University Press, ISBN 978-3-902571-97-7, Innsbruck

Jansen, E., Overpeck, J., Briffa, K.R., Duplessy, J.-C., Joos, F.V., Masson-Delmotte, D., Olago, B., Otto-Bliesner, W., Peltier, R., Rahmstorf, S., Ramesh, R., Raynaud, D., Rind, D., Solomina, O., Villalba, R. \& Zhang, D. (2007). Palaeoclimate, In: Climate Change 2007: The Physical Science Basis. Contribution of Working Group I to the Fourth Assessment Report of the Intergovernmental Panel on Climate Change, Solomon, S., Qin, D., Manning, M., Chen, Z., Marquis, M., Averyt, K.B., Tignor, M. \& Miller H.L., pp. 433-497, Cambridge University Press, ISBN 978-0-521-88009-1, Cambridge, UK, New York, NY

Joerin, U.E., Nicolussi, K., Fischer, A., Stocker, T.F. \& Schlüchter, C. (2008). Holocene optimum events inferred from subglacial sediments at Tschierva Glacier, Eastern Swiss Alps. Quaternary Science Reviews, Vol. 27, No. 3-4, (February 2008), pp. 337350, ISSN 0277-3791

Keller, F. (1987). Permafrost im Schweizerischen Nationalpark. Jahresbericht der Naturforschenden Gesellschaft Graubünden, Vol. 104, pp. 35-53, ISSN 0373-384X

Kerschner, H., Ivy-Ochs, S. (2008). Palaeoclimate from glaciers: Examples from the Eastern Alps during the Alpine Lateglacial and early Holocene. Global and Planetary Change, Vol. 60, No. 1-2, (January 2008), pp. 58-71, ISSN 0921-8181

Kohler, T. \& Maselli, D. (Eds.). (2009). Mountains and Climate Change - From Understanding to Action, Centre for Development and Environment (CDE), ISBN 978-3-905835-16-8, Bern

Krainer, K., Mostler, W. \& Spötl, C. (2007). Discharge from active rock glaciers, Austrian Alps: a stable isotope approach. Austrian Journal of Earth Sciences, Vol. 100, pp. 102112, ISSN 0251-7493

Kronberger, B., Balas, M. \& Prutsch, A. (Red.). (2010). Auf dem Weg zu einer nationalen Anpassungsstrategie, Policy Paper, Bundesministerium für Land- und Forstwirtschaft, Umwelt und Wasserwirtschaft (BMLFUW), 13.04.2011, Available from: http:/ / umwelt.lebensministerium.at/filemanager/download/68173/

Lambrecht, A. \& Kuhn, M. (2007). Glacier changes in the Austrian Alps during the last three decades, derived from the new Austrian glacier inventory. Annals of Glaciology, Vol. 46, No. 1, (October 2007), pp. 177-184, ISSN 0260-3055

Land Tirol (n.d.). Tiroler Kulturlandschaftsinventar, In: TIRIS Kartendienste, 27.04.2011, Available from: http://www.tirol.gv.at/themen/zahlen-und-fakten/statistiktiris/tiris-kartendienste

Lemke, P., Ren, J., Alley, RB., Allison, I., Carrasco, J., Flato, G., Fujii, Y., Kaser, G., Mote, P., Thomas, RH. \& Zhang, T. (2007). Observations: Changes in Snow, Ice and Frozen Ground, In: Climate Change 2007: The Physical Science Basis. Contribution of Working Group I to the Fourth Assessment Report of the Intergovernmental Panel on Climate 
Change, Solomon, S., Qin, D., Manning, M., Chen, Z., Marquis, M., Averyt, K.B., Tignor, M. \& Miller H.L., pp. 338-383, Cambridge University Press, ISBN 978-0521-88009-1, Cambridge, UK, New York, NY

Mathieu, J. (2011). Die dritte Dimension. Eine vergleichende Geschichte der Berge in der Neuzeit, Schwabe, ISBN 978-3-7965-2711-1, Basel

Meadows, D.H., Meadows, D.L., Randers, J. \& Behrens III, W.W. (1972). The limits to growth: a report for The Club of Rome's project on the predicament of mankind, Universe, ISBN 087663-165-0, New York, NY

Messerli, B. (2010). Mountains, their resources and risks - common goods or common concerns? In: Challenges for mountain regions. Tackling Complexity, Borsdorf, A., Grabherr, G., Heinrich, K., Scott, B. \& Stötter, J., pp. 211-218, Böhlau, ISBN 978-3205-78652-8, Vienna

Nicolussi, K. (1990). Bilddokumente zur Geschichte des Vernagtferners im 17. Jahrhundert. Zeitschrift für Gletscherkunde und Glazialgeologie, Vol. 26, No. 2, pp. 97-119, ISSN 0044-2836

Nicolussi, K., Kaufmann, M., Patzelt, G., van der Plicht, J. \& Thurner, A. (2005). Holocene tree-line variability in the Kauner Valley, Central Eastern Alps, indicated by dendrochronological analysis of living trees and subfossil logs. Vegetation History and Archaeobotany, Vol. 14, No. 3, (August 2005), pp. 221-234, ISSN 0939-6314

Olefs, M. \& Fischer, A. (2008). Comparative study of technical measures to reduce snow and ice ablation in Alpine glacier ski resorts. Cold regions science and technology, Vol. 52, No. 3, (May 2008), pp. 371-384, ISSN 0165-232X

Olefs, M., Fischer, A. \& Lang, J. (2010). Boundary conditions for artificial snow production in the Austrian Alps. Journal of Applied Meteorology and Climatology, Vol. 49, No. 6, (June 2010), pp. 1096-1113, ISSN 1558-8424

Patzelt, G. (1970). Die Längenmessungen an den Gletschern der österreichischen Ostalpen 1890-1969. Zeitschrift für Gletscherkunde und Glazialgeologie, Vol. 6, No. 1-2, pp. 151159, ISSN 0044-2836

Paul, F., Kääb, A. \& Haeberli, W. (2007). Recent glacier changes in the Alps observed by satellite: Consequences for future monitoring strategies. Global and Planetary Change, Vol. 56, No. 1-2, (March 2007), pp. 111-122, ISSN 0921-8181

Pauli, H., Gottfried, M., Reiter, K., Klettner, C. \& Grabherr, G. (2007). Signals of range expansions and contractions of vascular plants in the high Alps: observations (1994-2004) at the GLORIA master site Schrankogel, Tyrol, Austria. Global Change Biology, Vol. 13, No. 1, (January 2007), pp. 147-156, ISSN 1365-2486

Perlik, M. (1999). Urbanisationszonen in den Alpen. Ergebnis wachsender Pendeldistanzen. Revue de Géographie Alpine, Vol. 87, No. 2, pp. 147-165, ISSN 0035-1121

Permanent Secretariat of the Alpine Convention (Ed.). (2007). Transport and Mobility in the Alps, Alpine Convention, Available from:

http://www.alpconv.org/documents/Permanent_Secretariat/web/RSAI/RSA_en g_20071128_low.pdf

Pröbstl, U. (2006). Kunstschnee und Umwelt. Entwicklung und Auswirkungen der technischen Beschneiung, Haupt, ISBN 978- 3-258-06936-0, Bern

Schlagintweit, H. \& Schlagintweit, A. (1850). Untersuchungen über die physicalische Geographie der Alpen in ihren Beziehungen zu den Phaenomenen der Gletscher, zur Geologie, Meteorologie und Pflanzengeographie. Barth, Leipzig 
Schmidt, R., Kamenik, C., Tessadri, R. \& Koinig, K.A. (2006). Climatic changes from 12,000 to 4,000 years ago in the Austrian Central Alps tracked by sedimentological and biological proxies of a lake sediment core. Journal of Paleolimnology, Vol. 35, No. 3, (April 2006), pp. 491-505, ISSN 0921-2728

Slaymaker, O. (2001). Why so much concern about climate change and so little attention to land use change. The Canadian Geographer, Vol. 45, No. 1, (March 2001), pp. 71-78, ISSN 0008-3658

Smiraglia, C., Diolaiuti, G., Pelfini, M., Belò, M., Citterio, M., Carnielli, T. \& D’Agata, C. (2008). Glacier changes and their impacts on mountain tourism: two case studies from the Italian Alps, In: Darkening peaks: glacier retreat, science and society, Orlove, B., Wiegandt, E. \& Luckman, B.H., pp. 206-215, University of California Press, ISBN 978-0-520-25305-6, Berkeley, CA

Steiger, R. (2011). Climate Change Impact on Skiing Tourism in Tyrol (Austria, Italy). PhD Thesis, Universität Innsbruck

Steiger, R. \& Mayer, M. (2008). Snowmaking and Climate Change: Future Options for Snow Production in Tyrolean Ski Resorts. Mountain Research and Development, Vol. 28, No. 3-4, (August/November 2008), pp. 292-298, ISSN 0276-4741

Stötter, J. (1994). Veränderungen der Kryosphäre in Vergangenheit und Zukunft sowie Folgeerscheinungen - Untersuchungen in ausgewählten Hochgebirgsräumen im Vinschgau (Südtirol). Habilitation Thesis, Ludwig-Maximilian-Universität München

Stötter, J. (2007). Zunahme des Schadenspotentials und Risikos in Tirol als Ausdruck der Kulturlandschaftsentwicklung seit den 1950er Jahren, In: Alpine Kulturlandschaft im Wandel. Hugo Penz zum 65. Geburtstag, Innsbrucker Geographische Gesellschaft, pp. 164-178, ISBN 978-3-901182-86-0, Innsbruck

Stötter, J., Maukisch, M., Simstich, J. \& Belitz, K. (1996). Auswirkungen des zeitlichräumlichen Wandels der Permafrostverteilung im Suldental (Ortlergebiet) auf das Gefährdungspotential durch Erosionsprozesse im Lockermaterial, Tagungspublikation, Band 1, Internationales Symposium INTERPRAEVENT, pp. 447457, ISBN 3-901164-04-9, Garmisch-Partenkirchen, 1996

Stötter, J., Weck-Hannemann, H. \& Veulliet, E. (2009). Global Change and Natural Hazards: New Challenges, New Strategies, In: Sustainable Natural Hazard Management in Alpine Environments, Veulliet, E., Stötter, J. \& Weck-Hannemann, H., pp. 1-34, Springer, ISBN 978-3-642-03228-8, Heidelberg

Stützer, A. (2005): Bildsequenzen als Zeugen der Vegetationsdynamik in der subalpinen Höhenstufe der Koralpe (Kärnten/Österreich). Wulfenia, Vol. 12, pp. 127-138, ISSN 1561-882X

Tappeiner, U., Borsdorf, A. \& Tasser, E. (Eds.). (2008). Alpenatlas - Atlas des Alpes - Atlante delle Alpi-Atlas Alp - Mapping the Alps, Spektrum, ISBN 978-3-8274-2004-6, Heidelberg

Vincent, C., Kappenberger, G., Valla, F., Bauder, A., Funk, M. \& Le Meur, E. (2004). Ice ablation as evidence of climate change in the Alps over the 20th century. Journal of Geophysical Research - Atmospheres, Vol. 109, D10104, (May 2004), doi:10.1029/2003JD003857, ISSN 0148-0227

Wieser, G., Matyssek, R., Luzian, R., Zwerger, P., Pindur, P., Oberhuber, W. \& Gruber, A. (2009). Effects of atmospheric and climate change at the timberline of the Central European Alps. Annals of Forest Science, Vol. 66, No. 4, (June 2009), pp. 402-412, ISSN 1286-4560

Wyss, A. \& Arlanch, S. (2009). Bauen und Sanieren im Klimawandel, CIPRA, Available from: http://www.cipra.org/pdfs/782_de/at_download/file 


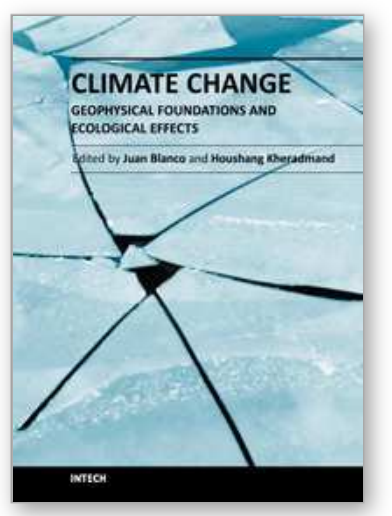

\author{
Climate Change - Geophysical Foundations and Ecological Effects \\ Edited by Dr Juan Blanco
}

ISBN 978-953-307-419-1

Hard cover, 520 pages

Publisher InTech

Published online 12, September, 2011

Published in print edition September, 2011

This book offers an interdisciplinary view of the biophysical issues related to climate change. Climate change is a phenomenon by which the long-term averages of weather events (i.e. temperature, precipitation, wind speed, etc.) that define the climate of a region are not constant but change over time. There have been a series of past periods of climatic change, registered in historical or paleoecological records. In the first section of this book, a series of state-of-the-art research projects explore the biophysical causes for climate change and the techniques currently being used and developed for its detection in several regions of the world. The second section of the book explores the effects that have been reported already on the flora and fauna in different ecosystems around the globe. Among them, the ecosystems and landscapes in arctic and alpine regions are expected to be among the most affected by the change in climate, as they will suffer the more intense changes. The final section of this book explores in detail those issues.

\title{
How to reference
}

In order to correctly reference this scholarly work, feel free to copy and paste the following:

Oliver Bender, Axel Borsdorf, Andrea Fischer and Johann Stötter (2011). Mountains Under Climate and Global Change Conditions - Research Results in the Alps, Climate Change - Geophysical Foundations and Ecological Effects, Dr Juan Blanco (Ed.), ISBN: 978-953-307-419-1, InTech, Available from:

http://www.intechopen.com/books/climate-change-geophysical-foundations-and-ecological-effects/mountainsunder-climate-and-global-change-conditions-research-results-in-the-alps

\section{INTECH}

open science | open minds

\section{InTech Europe}

University Campus STeP Ri

Slavka Krautzeka 83/A

51000 Rijeka, Croatia

Phone: +385 (51) 770447

Fax: +385 (51) 686166

www.intechopen.com

\section{InTech China}

Unit 405, Office Block, Hotel Equatorial Shanghai

No.65, Yan An Road (West), Shanghai, 200040, China

中国上海市延安西路65号上海国际贵都大饭店办公楼405单元

Phone: +86-21-62489820

Fax: $+86-21-62489821$ 
(C) 2011 The Author(s). Licensee IntechOpen. This chapter is distributed under the terms of the Creative Commons Attribution-NonCommercialShareAlike-3.0 License, which permits use, distribution and reproduction for non-commercial purposes, provided the original is properly cited and derivative works building on this content are distributed under the same license. 